\title{
Water and heat stress: the effect on the growth and yield of maize and the impacts on irrigation water
}

\author{
A. Garcia y Garcia 1 , M. A. Abritta 2 , C. M. T. Soler ${ }^{3}$ \& A. Green \\ ${ }^{I}$ Department of Plant Sciences, \\ University of Wyoming Research and Extension Center, USA \\ ${ }^{2}$ Department of Plant Sciences, University of Wyoming, USA \\ ${ }^{3}$ AgroFresh Inc., (Cody), USA \\ ${ }^{4}$ AgroFresh Inc., (Des Moines), USA
}

\begin{abstract}
The onset of water stress and the determination of heat stress on maize were studied using a ground-based remote sensing technique. The experiments were conducted at the University of Wyoming Research and Extension Center located in Powell, WY during the 2012 growing season on fields subjected to sub-surface drip irrigation (SDI), on-surface drip irrigation (ODI), and sprinkler (SPR) irrigation methods. In all three experiments the crop was subjected to three irrigation strategies, including $1.00 \mathrm{ETc}, 0.75 \mathrm{ETc}$ and $0.50 \mathrm{ETc}$. Throughout the growing season the canopy temperature was monitored with infrared thermometers (IRTs) and the environmental variables were monitored with an automated weather station that was located on site. The IRTs were set to automatically retrieve and transmit the data to a dedicated computer using data loggers and radio transmitters/receivers. The soil moisture was monitored weekly with a neutron probe to a depth of $1 \mathrm{~m}$. Plant samples for growth analysis were obtained regularly, and phenology observations were recorded bi-weekly. Photosynthesis was obtained in all treatments within each experiment using an infrared gas analyzer. Compared to the ODI and the SPR fields, water and heat stress had less effect on maize grown at the SDI field. Reduction on net photosynthesis was as little as 5.91 percent at the $0.75 \mathrm{ET}$ treatment of the SDI to as much as 65 percent at the $0.50 \mathrm{ET}$ treatment of the SPR. A functional relationship between the average crop water stress index (CWSI) and grain yield, was found. The use of IRTs for conditions in the semi-arid and arid regions of
\end{abstract}


Wyoming showed to be promising as long as the crop water stress index is kept near zero. Our results are encouraging and of special importance in times of declining water resources being available for crop production as may allow for further development of technologies for irrigation scheduling aiming at enhancing the water use and water productivity of crops.

Keywords: infrared thermometers, ground-based remote sensing, canopy temperature, crop water stress index, CWSI, maize water stress, maize heat stress, limited irrigation.

\section{Introduction}

Water and heat stress are among the most important abiotic stressors that affect crop production. This is especially true in semi-arid and arid regions, where water supplies for agricultural production are being reduced and where air temperature may reach levels above what is required for optimum plant growth, with a duration that may adversely affect crop production. Although most of the time both, water and heat stress occur simultaneously, the latter may be devastating even if soil moisture is suitable. This reflects the importance of water and heat stress in both irrigated and rainfed agriculture, therefore demonstrating the significance of developing approaches that could help to mitigate such effects in a timely manner.

The soil water threshold at which the growth of a plant is limited varies as a function of soil type, species and variety, plant growth stage, and environmental conditions. It has been demonstrated that water stress on maize prior to silking can reduce grain yield by 25 percent, water stress at silking can reduce grain yield by 50 percent, and water stress after silking can reduce grain yield by 21 percent [1]. In fact, water stress affects many different plant process [2]; including a reduction in leaf area index $[3,4]$, and if severe, water stress may drastically affect plants growth, with yield losses varying from 66 percent to nearly 100 percent in total yield loss [1,5]. Specifically, NeSmith and Ritchie [3] reported yield losses that ranged from 15 percent to 25 percent as a result of drought stress during the pre-anthesis stage. For severe water deficits during the grain-filling period, NeSmith and Ritchie [6] found that yield reductions ranged from 21 percent to 40 percent, with the kernel weight being the most affected component. The most critical period for water stress for a maize plant is between the two weeks prior to and after silking (Kiniry and Ritchie [7]). Drought stress prior to silking can cause a failure of ear development, while drought stress after pollination can cause a decline in the number of kernels [8]. Grant et al. [9] found that water stress prior to silking did not decrease the number of kernels per ear of maize, but rather drought during the early stages of grain development resulted in a significant reduction in the number of kernels. Andrade et al. [10] reported a limited partitioning of dry matter to reproductive tissues during the critical period around silking resulted in a low number of established kernels.

During heat stress plants open their stomata to transpire and cool their leaves [11]; if atmospheric demand is too high or heat stress is combined with water stress, plants will not be able to open their stomata and their leaf temperature will become too high [12]. Non-contact measurement of leaf temperature is often 
accomplished through the use of radiometric surface thermometers usually referred to as infrared thermometers (IRTs). The advantages of infrared thermometry in studies requiring plant temperature include: no physical contact with the plant, simple automation of data collection, and non-point measurements that accounts for the inherent spatial variability [13].

The canopy temperature $(T c)$ of plants has been measured with infrared thermometers (IRTs) for the past 50 years [14]. The use of IRTs flourished in the 1970 s and 1980s with the development of indices to determine water stress. In recent years there have been many advances in science and technology used to for monitoring the environment [15]. Some of the most used water stress indices are: the stress degree-day (SDD), corresponding to the sum of the difference between $T c$ and air temperature (Ta) [16], and the crop water stress index (CWSI), a normalization of the SDD based on the vapor pressure deficit (VPD) [17]. Both approaches have shown to be suitable for semi-arid and arid conditions [18-20], even with some obstacles, such as canopy cover and limitations for conditions with low VPD $[18,19]$.

The objectives of this study were to determine the onset of water stress and heat stress on maize using a ground-based remote sensing technique and how this impacts irrigation water amounts.

\section{Material and methods}

The experiments were conducted at the University of Wyoming Research and Extension Center located in Powell, WY during the 2012 growing season on sub-surface drip irrigation (SDI), on-surface irrigation drip irrigation (ODI), and sprinkler irrigation (SPR). Maize (229 VT3 - RR -; Croplan Genetics, 82 days to maturity) was planted on May 11, 2012 on conventionally tilled fields at a rate of 8.5 plants $\mathrm{m}^{-2}$ on rows spaced $0.56 \mathrm{~cm}$ using a RCBD with six replicates. Grain yield was obtained harvesting $5 \mathrm{~m}$ length of the central two rows at each plot on October 23, 2012.

In all three experiments (SDI, ODI, and SPR) the crop was subjected to three irrigation strategies, including crop evapotranspiration (ETc) at 100 percent $(1.00 \mathrm{ET}), 75$ percent $(0.75 \mathrm{ET})$, and 50 percent $(0.50 \mathrm{ET})$. Irrigation was triggered using a water balance approach following the procedure of FAO-56 [21], using the ASCE modified Penman-Monteith eqn [22] for reference evapotranspiration (ETo) estimations. All fields were fully irrigated (1.00ET) until the V6 (sixth leave unfolded) growth stage, from that stage on the irrigation treatments were applied. Irrigation was withheld on the $22^{\text {nd }}$ of July, at V10 (tenth unfolded leaf) growth stage at the SDI and ODI fields for 10 days and at R2 (blister) stage at the SPR field for 10 days; then irrigation was resumed to full irrigation in all treatments for the rest of the season. Thus, the results here presented correspond to the period from V10 (July $10^{\text {th }}$ ) to the middle of the R3 (milk) growth stage.

Canopy temperature was monitored with infrared thermometers (Apogee Instruments, Logan, UT-USA) set to automatically retrieve and transmit the data to a dedicated computer using CR1000 data loggers (Campbell Scientific, Logan, UT, USA) and radio transmitters/receivers. Environmental variables were 
monitored and recorded continuously during most of the growing season with an automated weather station (Campbell Scientific, Logan, UT, USA).

Soil moisture (data not shown) was monitored weekly with a neutron probe CPN 503 DR Hydroprobe (InstroTek Inc., Grand Rapids, MI-USA) at depth intervals of $0.20 \mathrm{~m}$ to $1 \mathrm{~m}$. Plant samples for growth analysis and LAI (LI-3100C; Li-COR BioScience, Lincoln, NE-USA) were obtained regularly, and phenology observations were recorded bi-weekly. Photosynthesis $(A)$ was obtained in all treatments within each experiment using an infrared gas analyzer (LI-6400XT Portable Photosynthesis System; LI-COR BioScience, Lincoln, NE-USA).

The CWSI, derived following the procedure suggested by Idso et al. [17], and the $T c$ and the canopy to air temperature difference $(\Delta T)$, were used as water and heat stress indices. The effect of water and heat stress on yield and other variables were estimated as the average difference between values computed for water stressed plots and control plots. The photosynthesis reduction was obtained as $(1-A o / A s) \times 100$, were $A o$ was the net photosynthesis $\left(\mu \mathrm{mol} \mathrm{m} \mathrm{m}^{-2} \mathrm{~s}^{-1}\right)$ under optimum conditions of water and $A s$ the net photosynthesis under stress conditions.

The effect of treatments and their interactions was analyzed performing ANOVA across experimental fields. A $t$-test was used to determine significant differences $(P<0.05)$ among means. Linear regression was used to test the relationship between variables. All statistical analyses were performed with SAS [23] and SigmaPlot ${ }^{\circledR}[24]$.

\section{Results and discussion}

\subsection{Weather conditions}

The experiments were planted on May $11^{\text {th }}$ but due to low temperatures around at the beginning of the season, with a couple of days of minimum temperature of $0^{\circ} \mathrm{C}$, the crop started with a growth. Some cold days around the second week of September did not compromise final yield but also delayed harvest time.

The 2012 growing season was characterized as extremely dry and warm. The rainfall recorded from May to October was $41 \mathrm{~mm}$, far below the $132 \mathrm{~mm}$ considered normal, while the average air maximum temperature was $25.5^{\circ} \mathrm{C}, 1.8^{\circ} \mathrm{C}$ above normal. The atmospheric demand for the season, estimated using the FAO Penman-Monteith eqn [21] modified by ASCE (22), was $685 \mathrm{~mm}$ for an overall water deficit of $644 \mathrm{~mm}$ (fig. 1).

\subsection{Effect of irrigation method and irrigation strategy on grain yield}

Within irrigation method, significant differences $(\mathrm{alpha}=0.05)$ on grain yield due to irrigation strategy, were observed. Overall, grain yield ranged from $11053 \mathrm{~kg}$ $\mathrm{ha}^{-1}$ for the $1.00 \mathrm{ET}$ treatment under the ODI to $3803 \mathrm{~kg} \mathrm{ha}^{-1}$ for the 0.50ET treatment under the SPR. Grain yield in the ODI $>$ SDI $>$ SPR in the full irrigated $(1.00 \mathrm{ET})$ treatments while limited irrigation $(0.75 \mathrm{ET}$ and $0.50 \mathrm{ET})$ tended to be SDI $>$ ODI $>$ SPR (table 1). The higher yield at the ODI in the 1.00ET treatment 
may be explained because of the localized delivery of water on top of the soil surface, facilitating its infiltration in the root zone as opposed to the SDI, in which water was delivered at $0.30 \mathrm{~m}$ depth. Reduced evaporation losses may be the main reason for better yield with limited irrigation in the ODI and the SDI.

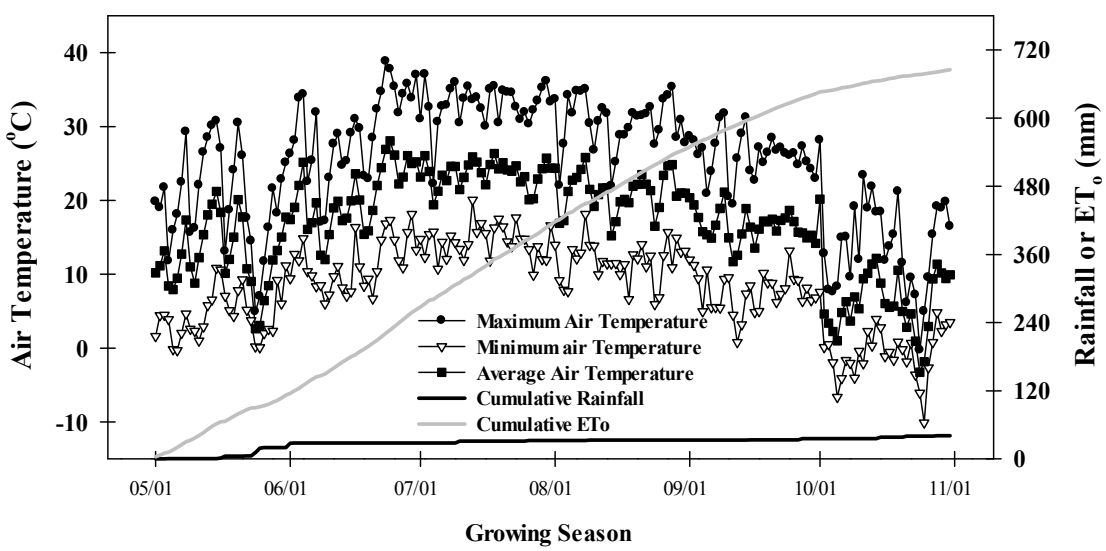

Figure 1: Weather conditions during the 2012 growing season (May-October) at the University of Wyoming Research and Extension Center located in Powell, WY, USA.

Table 1: Maize yield as affected by irrigation method and irrigation strategy.

\begin{tabular}{lccc}
\hline $\begin{array}{c}\text { Irrigation } \\
\text { Treatment }\end{array}$ & SDI & ODI & SPR \\
\hline $1.00 \mathrm{ET}$ & $10946 \mathrm{a} \S$ & $11053 \mathrm{a}$ & $10900 \mathrm{a}$ \\
$0.75 \mathrm{ET}$ & $10355 \mathrm{~b}$ & $8753 \mathrm{~b}$ & $8612 \mathrm{~b}$ \\
$0.50 \mathrm{ET}$ & $9068 \mathrm{c}$ & $7586 \mathrm{c}$ & $3803 \mathrm{c}$ \\
\hline LSD & 946 & 1068 & 690
\end{tabular}

$\S$ Within column, means with the same letter are not significantly different at alpha $=0.05$.

Due to weather conditions, the temporary termination of irrigation at the SPR field was delayed 5 days. To avoid extreme water stress at the $0.75 \mathrm{ET}$ and $0.50 \mathrm{ET}$ treatments, an irrigation event was triggered in the whole field. This measure, however, was severe enough to provoke considerable reduction on grain yield of maize at the 0.50ET treatment of the SPR field.

The SDI had the least yield reduction, varying between -5 and -17 percent for the $0.75 \mathrm{ET}$ and $0.50 \mathrm{ET}$ treatments, respectively. The ODI and SPR fields had identical yield reduction for the $0.75 \mathrm{ET}$ irrigation treatment (-21 percent) while the yield reduction of the 0.50ET irrigation treatment was -65 percent at the SPR field and -31 percent at the ODI field (table 2). 
Table 2: Yield reduction as affected by irrigation method and irrigation strategy.

\begin{tabular}{|c|c|c|c|}
\hline \multirow{2}{*}{$\begin{array}{l}\text { Irrigation } \\
\text { Treatment }\end{array}$} & \multicolumn{3}{|c|}{ Yield Reduction (percent) $\$$} \\
\hline & SDI & ODI & SPR \\
\hline $0.75 \mathrm{ET}$ & -5 & -21 & -21 \\
\hline $0.5 \mathrm{ET}$ & -17 & -31 & -65 \\
\hline
\end{tabular}

\subsection{Variations on canopy temperature and canopy to air temperature}

The highest canopy temperatures for the period between V10 and R3 were observed/recorded from $12 \mathrm{pm}$ to $5 \mathrm{pm}$, as indicated by the yellow and orange colors in fig. 2. The treatments of 1.00ET had lower canopy temperatures, followed by the $0.75 \mathrm{ET}$ and $0.50 \mathrm{ET}$. As the effect of water stress increased, Tc increased to as much as $36^{\circ} \mathrm{C}$ and $37^{\circ} \mathrm{C}$ at the ODI and SPR fields. Interestingly, $T c$ at the SDI did not reach the expected high levels, probably due to higher available water in the soil profile, allowing for transpiration to continue cooling the leaves.

SDI

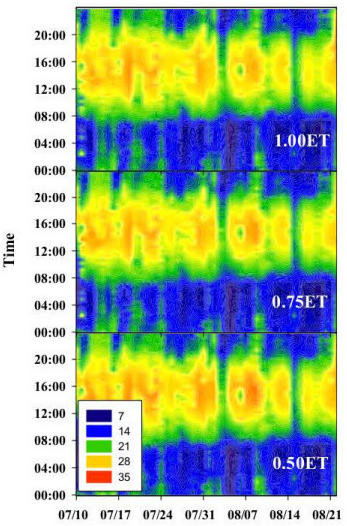

ODI

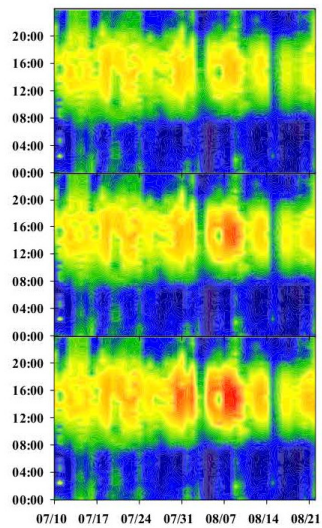

SPR

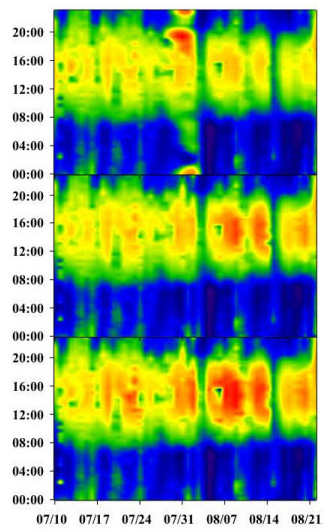

Figure 2: Temporal variation of $T c$ on maize grown on sub-surface drip irrigation (SDI), on-surface drip irrigation (ODI), and lateral move sprinkler irrigation (SPR) systems and three irrigation strategies (1.0ET, 0.75ET, 0.50ET). 
For the period from V10 to R3 the average $\Delta T$ was positive (canopy temperature higher than air temperature) in all irrigation methods and irrigation treatments from around $9 \mathrm{am}$ to $3 \mathrm{pm}-4 \mathrm{pm}$. The highest positive $\Delta T$ during such period were observed and recorded from $11 \mathrm{pm}$ to $3 \mathrm{pm}$, as indicated by the yellow and orange colors in fig. 3 . Overall, the average $\Delta T$ was $1.00 \mathrm{ET}<0.75 \mathrm{ET}$ $<0.50 \mathrm{ET}$. As the effect of water stress increased, the maximum positive $\Delta T$ increased to as much as $4.2^{\circ} \mathrm{C}$ at the ODI and SPR fields for the $0.50 \mathrm{ET}$ treatments and remained at around $3.2^{\circ} \mathrm{C}$ for the SDI in all irrigation treatments. This almost even maximum $\Delta T$ among SDI treatments is most likely due to the duration not being as long in this field as in the ODI field. The duration and intensity of a positive $\Delta T$ was higher at the SPR field, were delayed termination of irrigation considerably affected yield.

SDI

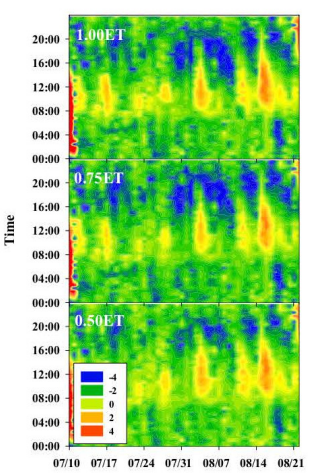

ODI

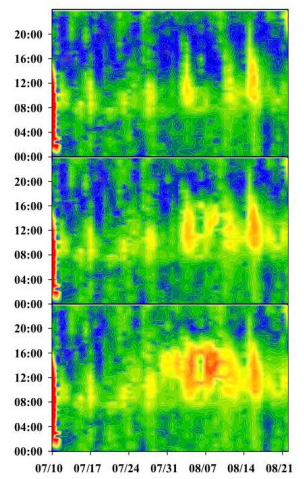

SPR

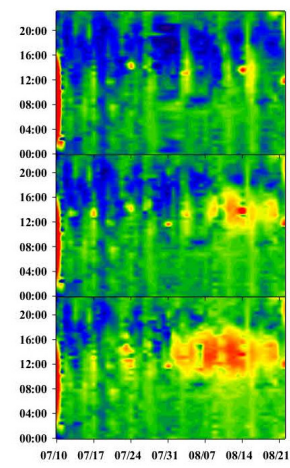

Figure 3: $\quad$ Temporal variation of canopy to air temperature difference $(\Delta T)$ on maize grown on sub-surface drip (SDI), on-surface drip (ODI), and lateral move sprinkler (SPR) irrigation methods and three irrigation strategies (1.0ET, 0.75ET, 0.50ET).

\subsection{Effect of irrigation method and irrigation strategy on photosynthesis and CWSI}

The average CWSI from 10am to $6 \mathrm{pm}$ showed that maize grown in the SDI field was less stressed than the ODI and SPR fields for the period between V10 and R3 (fig. 4). This was confirmed with the $A$ reduction, which also followed the same pattern of SDI $<$ ODI $<$ SPR. Maize grown under the SPR showed a delay on becoming stressed when compared with the SDI and ODI probably due to differences in irrigation dates. It is important to consider that the flowering or VT stage was reached between July 23-26, and increased values of CWSI were recorded around flowering and early grain filling stages which are reported as critical periods for corn sensitivity to drought and heat stress. 

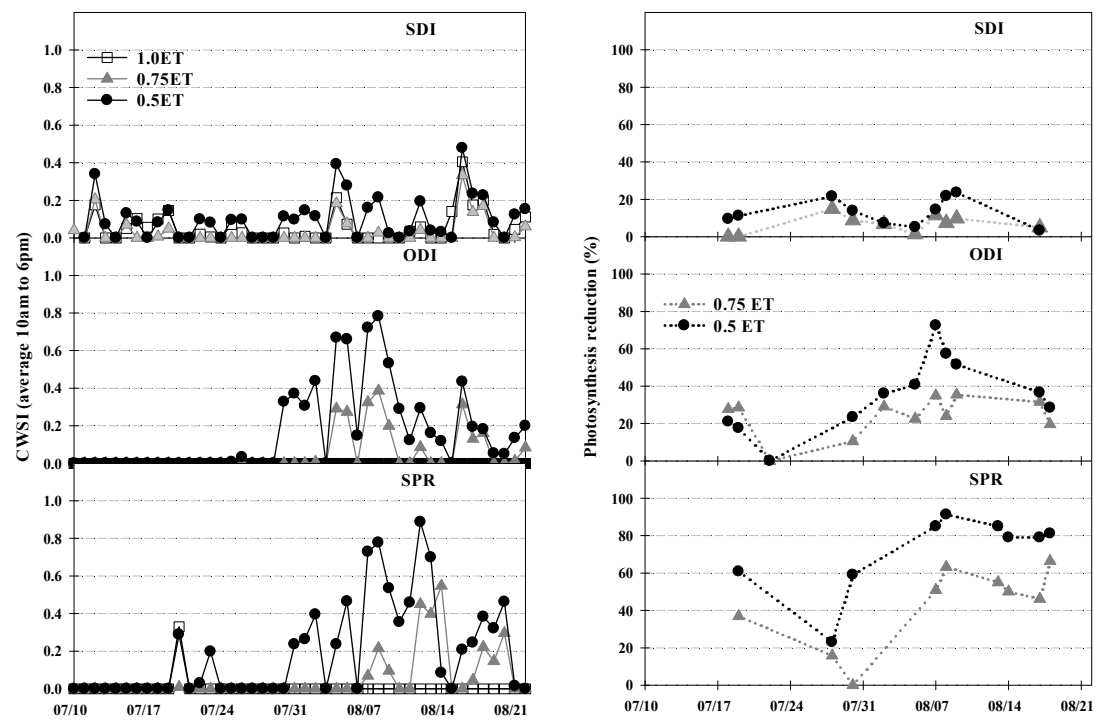

Figure 4: Effect of crop water stress on photosynthesis reduction on maize grown under three irrigation methods and three irrigation strategies.

The average reduction on photosynthesis was 20 percent and 31 percent at the ODI field for the $0.75 \mathrm{ET}$ and $0.50 \mathrm{ET}$, respectively. At the SDI field the reduction was 6 percent and 13 percent for the $0.75 \mathrm{ET}$ and $0.50 \mathrm{ET}$ irrigation treatments, respectively while at the sprinkler field, the photosynthesis reduction was more pronounced, 40 percent and 67 percent for the $0.75 \mathrm{ET}$ and the 0.50ET, respectively (table 3 ).

Table 3: Photosynthesis reduction as a function of irrigation method and irrigation strategy.

\begin{tabular}{llll}
\hline Irrigation Method & Irrigation Treatment & Size & A reduction (\%) \\
\hline \multirow{2}{*}{ SDI } & $0.75 \mathrm{ET}$ & 10 & 5.91 \\
& $0.50 \mathrm{ET}$ & 10 & 13.20 \\
\hline \multirow{2}{*}{ ODI } & $0.75 \mathrm{ET}$ & 13 & 19.61 \\
& $0.50 \mathrm{ET}$ & 13 & 30.62 \\
\hline \multirow{2}{*}{ SPR } & $0.75 \mathrm{ET}$ & 9 & 39.67 \\
& $0.50 \mathrm{ET}$ & 9 & 65.74 \\
\hline
\end{tabular}




\subsection{Grain yield as affected by heat and water stress}

For the period between V10 and R3 from 10am to $6 \mathrm{pm}$ and with respect to the canopy temperature of the $1.00 \mathrm{ET}$, the average increase on maize canopy temperature at the SDI field was only 2 percent. For the same period, the average canopy temperature at the ODI field showed an increase of 4 percent and 7 percent for the irrigation treatments of $0.75 \mathrm{ET}$ and $0.50 \mathrm{ET}$, respectively. The increase in average canopy temperature at the sprinkler irrigated field was 4 percent and 10 percent in the $0.75 \mathrm{ET}$ and $1.00 \mathrm{ET}$ treatments, respectively. As the soil moisture was depleted, the average positive $\Delta T$ was observed from around 9am to $6 \mathrm{pm}$; that increase corresponded to 33 percent, 70 percent and 75 percent in the $0.50 \mathrm{ET}$ treatments at the SDI, ODI and SPR irrigation methods, respectively.

From the three indices utilized to determine water and heat stress, the average CWSI from 10am to $6 \mathrm{pm}$ and for the period V10 to R3 was better related $\left(\mathrm{r}^{2}=0.81 ; \mathrm{P}=0.0009\right)$ to grain yield than a single $T c$ or $\Delta T$. It is clear that for the semi-arid conditions, WY, the irrigation strategies should focus on keeping the $C W S I$ values near 0 to avoid significant yield reduction. Further studies are being conducted to develop ground-based remote sensing irrigation scheduling technologies aiming at optimizing the water productivity of crops.

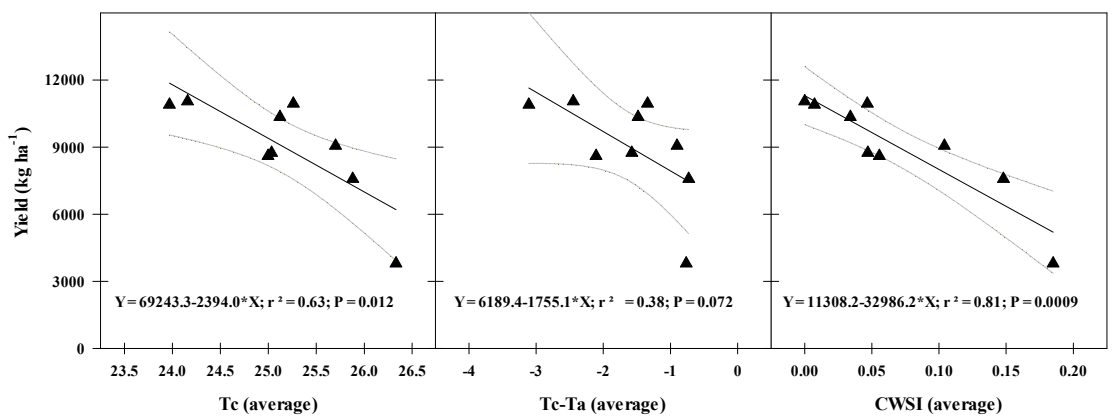

Figure 5: Relationship between canopy temperature $(T c)$, canopy to air temperature difference $(\Delta T)$, and crop water stress index (CWSI) on maize yield grown under three irrigation methods and three irrigation treatments.

\section{Conclusions}

Within irrigation method the grain yield of maize was significantly $(\mathrm{P}<0.05)$ affected the irrigation strategy. Grain yield of maize ranged from $11053 \mathrm{~kg} \mathrm{ha}^{-1}$ in the full irrigated treatment (1.00ET) of the on-surface drip irrigated field to 3803 $\mathrm{kg} \mathrm{ha}^{-1}$ in the less irrigated treatment $(0.50 \mathrm{ET})$ of the sprinkler irrigated field. Compared to the ODI and the SPR fields, water and heat stress had less effect on maize grown at the SDI field. Reduction on net photosynthesis was as little as 5.91 percent at the $0.75 \mathrm{ET}$ treatment of the SDI to as much as 65 percent at the $0.50 \mathrm{ET}$ 
treatment of the SPR. A functional relationship between the average crop water stress index (CWSI) and grain yield, was found. The use of IRTs for conditions in the semi-arid and arid regions of Wyoming showed to be promising as long as the crop water stress index is kept near zero. Our results are encouraging and of special importance in times of declining water resources being available for crop production as may allow for further development of technologies for irrigation scheduling aiming at enhancing the water use and water productivity of crops.

\section{References}

[1] Denmead, O.T. \& Shaw, R.H., The effects of soil moisture stress at different stages of growth on the development and yield of corn. Agron. J., 52(5), pp. 272-274, 1960.

[2] Hsiao, T. C. , E. Acevedo, E. Fereres, \& D. W. Henderson, Water Stress, Growth, and Osmotic Adjustment. Phil. Trans. R. Soc. B Biological Sciences, 273, pp. 479-500, 1976.

[3] NeSmith, D.S., Ritchie, J.T., Short- and long-term responses of corn to preanthesis soil water deficit. Agron. J., 84, pp. 107-113, 1992 a.

[4] Soler, C.M.T., Hoogenboom, G., Sentelhas, P.C. and Duarte, A.P., Impact of water stress on maize grown off-season in a subtropical environment. Journal of Agronomy and Crop Science, 193, pp. 247-261, 2007.

[5] Çakir, C., Effect of water stress at different development stages on vegetative and reproductive growth of corn. Field Crops Research, 89, pp. 1-16, 2004.

[6] NeSmith, D.S. \& Ritchie, J.T., Maize (Zea mays L.) response to a severe soil water-deficit during grain-filling. Field Crops Res., 29, pp. 23-35, $1992 b$.

[7] Kiniry, J. R. \& J. T. Ritchie, Shade-sensitive interval of kernel number of maize. Agron. J., 77, pp. 711-715, 1985.

[8] Harder, D., Carlson, R.E. \& Shaw, R.H., Yield and yield components and nutrient content of corn grain as influenced by post-silking moisture stress. Agron. J., 174, pp. 275-278, 1982.

[9] Grant, R. F., Jackson, B.S., Kiniry, J.R. \& Arkin, G.F., Water deficit timing effects on yield components in maize. Agron. J., 81, pp. 61-65, 1989.

[10] Andrade, F.H., Cirilo, A., Uhart, S., \& Otegui, M.E., Determinación del rendimiento. L. Barrosa, ed., In: Ecofisiología del cultivo de maíz, pp. 81-99. Balcarce, Buenos Aires, Argentina (in Spanish), 1996.

[11] Rizhsky, L., Liang, H., \& Mittler, R., The combined effect of drought stress and heat shock on gene expression in tobacco. Plant Physiol., 130, pp. 1143-1151, 2002.

[12] Mittler, R., Abiotic stress, the field environment and stress combination. TRENDS in Plant Science, 11(1), pp. 15-19, 2006.

[13] Mahan, J.R. \& Yeater, K.M., Agricultural applications of a low-cost infrared thermometer. Computers and Electronics in Agriculture, 64, pp. 262-267, 2008. 
[14] Fuchs, M \& Tanner, C.B., Infrared thermometry of vegetation. Agron. J., 58, pp. 597-601, 1966.

[15] Mahan J.R., Young A.W., Payton P., Deficit irrigation in a production setting: canopy temperature as an adjunct to ET estimates. Irrig. Sci. 30, pp. 127-137, 2012.

[16] Jackson, R.D., Reginato, R.J., \& Idos, S.B., Wheat canopy temperature: a practical tool for evaluating water requirements. Water Resources Research, 13(3), pp. 651-656, 1977.

[17] Idso, S.B., Jackson, R.D., Pinter Jr., P.J., Reginato, R.J., \& Hatfield, J.A., Normalizing the stress-degree-day parameter for environmental variability. Agricultural Meteorology, 24, pp. 45-55, 1981.

[18] Keener, M.E. \& Kircher, P.L., The use of canopy temperature as an indicator of drought stress in humid regions. Agricultural Meteorology, 28, pp. 339-349, 1983.

[19] Colaizzi, P.D., O’Shaughnessy, S.A., Evett, S.R., Howell, T.A. Using plant canopy temperature to improve irrigated crop management. In: Proceedings of the 24th Annual Central Plains Irrigation Conference, Colby, Kansas, February 21-22, 2012.

[20] Cárcova, J., Maddonni, G.A., \& Ghersa, C.M., Crop water stress index of three maize hybrids grown in soils with different quality. Field Crops Research, 55, pp. 165-174, 1999.

[21] Allen R.G., Pereira L.S., Raes D. \& Smith M., Crop evapotranspiration: Guidelines for computing crop requirements. Irrigation and Drainage Paper No. 56, FAO, Rome, Italy, 1998.

[22] Walter I.A., Allen R.G., Elliott R., Mecham B., Jensen M.E., Itenfisu D., Howell T.A., Snyder R., Brown P., Echings S., Spofford T., Hattendorf M., Cuenca R.H., Wright J.L. \& Martin D., ASCE Standardized Reference Evapotranspiration Equation, p. 209-215. In: Evans RG, Benham BL, Trooien TP (eds.) Proc. National Irrigation Symposium, ASAE, Nov. 14-16, 2000, Phoenix, AZ. 2000.

[23] SAS Institute Inc., 2009. SAS OnlineDoc ${ }^{\circledR}$ 9.2. SAS Institute Inc., Cary, NC.

[24] SigmaPlot 12.3. Software for Windows 7. Systat Software, Inc., San Jose, CA, 2006. 